\title{
Column
}

\section{Professoraal versus professioneel}

\section{Hans Jägers}

De wereld om ons heen is fascinerend en boeiend, vooral wanneer deze in de positie van een betrekkelijke buitenstaander in ogenschouw kan worden genomen. Zodra de betrokkenheid toeneemt, kan deze houding echter veranderen in een angstige, uitdagende of een ontkennende. 'Irak' is ver weg en lijkt voor velen te ontaarden in een interessant spelletje stratego, waarin slechts op het spelbord van de geest slachtoffers kunnen vallen en machtsevenwichten kunnen verschuiven. De directe aantasting van de economische ordening door toenemende rentestijgingen, vergroting van de werkloosheid en teruglopende bedrijfsresultaten maakt ons echter direct medespeler op het bord van de maatschappelijke sturing. Onzekerheid is troef en de toekomst gaat schuil achter onvoorspelbare en nauwelijks te beïnvloeden variabelen. Wie stuurt en wie wordt bestuurd?

Deze zelfde vraag zullen vele organisaties zich momenteel stellen die met tegenvallende resultaten worden geconfronteerd. De afgelopen maanden is er bijna geen week voorbijgegaan zonder berichten over negatieve groeiverwachtingen. Het heeft erop geleken dat het wereldwijd omvallen van Philips voor vele ondernemingen als een steen in een dominospel heeft gewerkt (NedLloyd, IBM, KLM, DAF). De nationale en internationale concurrentieslag wordt heviger en de strijd om de gunst van de klant komt nog centraler te staan. Nieuwe managers staan op en andere structuren worden in het leven geroepen om het tij te keren en de levensvatbaarheid van de toekomst (weer) te garanderen. Het besturingsproces wordt cruciaal en is meer dan ooit een professionele opgave.

Voor iedere organisatie die een produkt levert is de klantgerichtheid, het luisteren naar wat de klant wil en daarop tijdig weten in te spelen, een vereiste. Ook voor de universitaire onderwijsinstellingen gaat deze waarheid op. In november meldde de Volkskrant in een speciale bijlage dat de relatie student-onderwijsinstelling aan vernieuwing toe is. 'Onderwijs is een produkt. Als dat produkt niet voldoet, moet je klagen. Met een brood dat beschimmelt blijkt, ga je immers ook terug naar de bakker. De verhouding studentonderwijsinstelling wordt steeds meer een relatie klant-leverancier.'

$\mathrm{Nu}$ is er in de aansturing van de universiteiten in de achterliggende perioden het nodige gebeurd. Aanvankelijk vertoonde de universitaire organisatie trekken van een corporatief verband waarin zelfstandige individuen die niet zijn gebonden door hun sociale positie samenwerken. De structuur die daarin is aangebracht door de Wet op het wetenschappelijk onderwijs, verschafte niet alleen een zekere autonomie aan de universiteiten, maar bracht ook een grotere verantwoordelijkheid mee voor de eigen bedrijfsvoering. Onder invloed van schaalvergroting, veranderende verhoudingen tussen geldschieter (overheid) en universiteiten en toenemende studentenaantallen wordt het managementproces ook daar steeds zwaarder en ingewikkelder.

Zoals bij vele ondernemingen die onder druk kwamen te staan en met groei kregen te maken, vertoonde ook de universitaire organisatie toenemende trekken van een bureaucratische organisatie. Het centrale bestuursproces werd als

Dr. H. P. M. Jägers, geboren in 1941, studeerde organisatiesociologie aan de RUL. Promoveerde in 1985 aan de faculteit der economische wetenschappen en econometrie van de UvA. Sinds 1987 als universitair hoofddocent verbonden aan de FEE van de UVA. Per 1 februari 1991 hoogleraar bedrijfskunde aan de KMA te Breda. 


\section{MAB}

steeds belangrijker beschouwd, waardoor de centrale diensten zich alsmaar versterkten. Het primaire proces van onderwijs en onderzoek op facultair niveau neigde bestuurlijk uit het zicht te verdwijnen. Faculteiten hebben deze bestuurlijke onderwaardering voor willen zijn en het spel als een uitdaging opgevat. We zien steeds meer faculteiten zich op het ondernemingspad begeven om een grotere (financiële) onafhankelijkheid te verwerven van het centrale universitaire bestuur. Met name geldt dit voor die faculteiten die qua vakgebied hiervoor de basisvoorwaarden in eigen hand hebben. Technische en sociaalwetenschappelijke faculteiten zijn zich al enkele jaren als zodanig aan het profileren. Overigens is het interessant te zien dat universiteiten bij een dalend reëel uitgavenniveau de onderzoeksoutput hebben weten te verhogen en de onderwijsrendementen konden verbeteren. Deze constatering geeft echter geen enkel antwoord op de vraag naar het zeker stellen van de kwaliteit.

Kwaliteitsborging is een vraagstuk dat ligt ingebed in een organisatorische context, waarin visie en vormgeving nauw op elkaar aansluiten. Om kwaliteit te kunnen behalen moet een hele organisatie hierbij betrokken zijn. De klant dwingt hiertoe. We zien dat organisaties andere structuren gaan aannemen om de voorwaarden te kunnen scheppen voor het realiseren van programma's van kwaliteitsverbetering. Dichter bij de klant staan en tijdig weten in te spelen op zijn eisen noodzaken niet alleen een grotere kennis van en betrokkenheid bij de omgeving van de organisatie, maar vragen ook om een management waarin eigen verantwoordelijkheid voor het besturen en de resultaten van de organisatie-eenheid (lees: faculteit) centraal staan. Het bestuurlijk concept van de business-unit lijkt het meest te voldoen aan het realiseren van de vraag om kwaliteit. Business-units hebben hun eigen afnemers die kwaliteitsprodukten en -diensten verlangen en die de producent ter verantwoording kunnen roepen als deze niet aan de gestelde eisen voldoet.

Het lijkt tijd faculteiten als dergelijke zelfstandige eenheden met een eigen verantwoordelijkheid naar hun eigen klanten/afnemers (studenten/ opdrachtgevers voor onderzoek) te gaan opvatten. Dit betekent overigens niet dat daarmee een los staan van de voorwaardenscheppende centrale eenheid een gevolg zou zijn. Geenszins, zou ik zeggen. Juist in een decentrale sturing met eigen verantwoordelijkheden is een overkoepelende instantie nodig, die over de zelfstandige eenheden heen algemene beleidslijnen uitzet en ze bewaakt.

De tijd om het huidige bestuurlijke stelsel als een boeiend en interessant fenomeen te beschouwen is voorbij. Klant en producent zien uitdagingen en onzekerheden in het verschiet liggen. Bestuur en stuurman dienen kracht en visie uit te stralen. Professoraal bestuur, dat wil zeggen bestuur dat traditioneel door professoren wordt voorgezeten, zal moeten wijken voor professioneel bestuur.

Een ieder zichzelf respecterende faculteit verdient een professioneel management. Ook faculteiten hebben een stuurman nodig die:

- zorg draagt dat de organisatie haar primaire doel, een effectieve en doelmatige voortbrenging van bepaalde goederen, realiseert;

- de stabiliteit van (het functioneren van) de organisatie vorm geeft en in stand houdt;

- zich belast met de ontwikkeling van de strategie en ervoor zorgt dat de organisatie optimaal aangepast is en blijft aan de omgeving;

- zorgt dat de organisatie de doelen dient van hen die de organisatie beheersen;

- fungeert als sleutelfiguur bij de informatie-uitwisseling tussen de organisatie en haar omgeving;

- verantwoordelijk is voor een optimale positie van zijn organisatie in termen van status en imago.

Het is nagenoeg ondenkbaar dat de bestuurlijke professionalisering die in velerlei professionele organisaties zoals bijvoorbeeld in ziekenhuizen door vallen en opstaan is doorgevoerd, ook niet op facultair niveau in universiteiten plaats gaat vinden.

Een decaan die professoraal zijn deskundigheid heeft bewezen, is nog steeds een goudvink als professioneel bestuurder. Dit is ook niet zo vreemd, omdat beide processen vanuit verschil- 
lende attitudes en visies worden aangestuurd. In de praktijk blijken zij elkaar ook nauwelijks te verdragen. In deze 'mismatch' staan klant en producent al lang niet meer gefascineerd toe te kijken, maar blikken zij geinteresseerd naar het behoud van de kwaliteit van hun toekomst.

Tot slot: het zou goed zijn als de klant-student zichzelf niet ten onder laat gaan in het democratiseringsstreven. Deelname aan het bestuur via gekozen vertegenwoordigers wekt de illusie meer dan formeel mede te kunnen beslissen over beleidsaangelegenheden.

Het overwicht in kennis en informatie bij het wetenschappelijk personeel in het bestuur maakt de democratisering tot een ritueel. Invloed uitoefenen op en meebepalen van beleid vanuit een onevenwichtige kennis- en informatiepositie komt daarmee in een sceptisch daglicht te staan en maakt de klant de facto monddood.

De klant-student zou er goed aan doen zich 'slechts' als toezichthoudend orgaan op te stellen op het gebied van het onderwijs, om daar waar de kwaliteit wordt aangetast deze bestuurlijk en publiekelijk aan de kaak te stellen. Een professioneel bestuur dient dit toezicht in haar beleid te integreren.

\section{Literatuur}

Groot, T. L. C. M., Management van universiteiten, WoltersNoordhoff, Groningen, 1988.

Veld, R. J. in 't, Doelmatigheid en de grote operaties, in: P. B. Boorsma, J. B. J. Koelman, Doelmatigheid in het hoger onderwijs, Vuga Uitgeverij B.V., 's-Gravenhage, 1986.

Mintzberg. $\mathrm{H}$. . The nature of managerial work, Prentice Hall, Englewood Cliffs, 1973.

Berg. A. H. , Managers bij de overheid, Vuga Uitgeverij B.V., 's-Gravenhage, 1988.

Dijck, J. J. J., Medezeggenschap in vergelijkend perspectief, Kluwer, Deventer, 1982.

\section{Toekenning Mr. Dr. J. H. R. Sinninghe Damsté-prijs 1990}

Tijdens de ledenvergadering van het NIvRA, gehouden op 12 december jongstleden is de Mr. Dr. J. H. R. Sinninghe Damsté-prijs 1990 uitgereikt aan Drs. R. J. M. Dassen voor zijn artikel 'De leer van het gewekte vertrouwen: Agency avant la lettre?', dat is gepubliceerd in het MAB van september 1989.

De redactie wenst de auteur van harte geluk met de toekenning van deze prijs. 